\title{
Re Hughes, deceased
}

Manchester Consistory Court: Tattersall Ch, August 2010 Exhumation - family disagreement - exceptional circumstances

After the death of the deceased a disagreement arose between her five children, two of whom interred her cremated remains in the parents' grave, concealing the same from the deceased's widower and the other children. When those children eventually discovered the whereabouts of the deceased's remains, a faculty was sought - for their exhumation and their reinterment in the deceased's widower's local churchyard in anticipation of his remains ultimately being interred with those of the deceased. In refusing the faculty, the chancellor held that the fact that the majority of the family wished for the remains to be interred elsewhere would not alone justify an exhumation. He accepted that, prior to her death, the deceased had indicated an intention that her remains be buried with her parents. He was not satisfied that she had had any intention of being interred with her husband. No exceptional circumstances were found and the application was rejected. [RA]

doi:10.1017/So956618X10001092

\section{Re St Michael, Cornhill}

London Consistory Court: Seed Ch, August 2010

Bells - replacement

The incumbent and churchwardens sought a faculty to dispose of nine of the church's ring of 12 bells for hanging elsewhere, to retain three as chiming bells and to introduce 12 new bells to the tower, with related ancillary works. The overall effect would be to have a ring of bells with true harmonic tuning which were lighter and easier to ring and which would cause two-thirds less movement in the tower during ringing. The project was costly, but significant funds were in place to cover the cost, including the trade-in value of the nine bells to be disposed of. There were a large number of individual objectors, and objections included suggestions that the existing ring of bells was the only 'old style' ring in the vicinity and that the bells had been originally cast, some recast and all maintained by one bell foundry, whereas the contract for the new bells had been given to another foundry. In granting the faculty the chancellor found inter alia that the claims about the unique 'old style' ring of bells were untrue and pointed to other examples in the City of London and nearby. In addition it was not within the jurisdiction of the court to direct how a private donor should spend their money, nor to direct petitioners to select any particular commercial company to carry out the works. [WA] 